\title{
CAG REPEAT POLYMORPHISM OF THE MITOCHONDRIAL DNA POLYMERASE GAMMA GENE IN MACEDONIAN INFERTILE AND FERTILE MEN
}

\author{
Plaseski $\mathrm{T}^{1,2}$, Noveski $\mathrm{P}^{1}$, Dimitrovski $\mathrm{C}^{2}$, Efremov GD ${ }^{1}$, \\ Plaseska-Karanfilska $\mathrm{D}^{1}$
}

*Corresponding Author: Dr. Dijana Plaseska-Karanfilska, Macedonian Academy of Sciences and Arts, Research Center for Genetic Engineering and Biotechnology, Av. Krste Misirkov 2, POB 428, 1000 Skopje, R. Macedonia; Tel.: +389-2-3235-410; Fax: +389-2-3115-434; E-mail: dijana@manu.edu.mk

\begin{abstract}
The catalytic subunit of human mitochondrial DNA polymerase gamma (POLG) is encoded by the POLG gene, located on chromosome 15q24 and includes a polymorphic CAG repeat. Analysis of POLG genotypes in some populations has identified an association between the absence of the $10 \mathrm{CAG}$ repeat allele and male infertility and suggested that POLG gene polymorphism should be considered as a possible contributing factor in cases with idiopathic subfertility with normal spermiograms. We undertook to assess whether different POLG CAG alleles are associated with impaired spermatogenesis and infertility/subfertility in Macedonian men. We studied 225 infertile/subfertile men (74 with azoospermia, 56 with severe oligozoospermia, 27 with mild oligozoospermia, 39 with unexplained infertility and normal sperm counts, and 29 with known causes of infertility) and a control group of 123 proven fathers, by fluorescent polymerase chain reaction (PCR) and
\end{abstract}

Macedonian Academy of Sciences and Arts, Research Center for Genetic Engineering and Biotechnology, Skopje, R. Macedonia

2 Faculty of Medicine, Clinic of Endocrinology and Metabolic Disorders, Skopje, R. Macedonia analysis on an ABI PRISMTM 310 Genetic Analyzer. The most frequently observed POLG allele was the common one of $10 \mathrm{CAG}$ repeats with a frequency of $87.6 \%$ in the infertile/subfertile group and $86.6 \%$ in the control group. The homozygous mutant POLG genotype (not10/not10) was found in both groups, $1.6 \%$ in the infertile/subfertile patients and $1.8 \%$ in the controls. In conclusion, our study showed no association between polymorphism of the POLG gene and infertility in Macedonian men.

Key words: Male infertility; Mitochondrial DNA polymerase gamma (POLG) gene; CAG repeat

\section{INTRODUCTION}

Infertility/subfertility affects approximately $5-7 \%$ of the male population worldwide and may increase in the future [1]. Infertility/subfertility of undefined cause is referred to as idiopathic infertility/subfertility, but is likely to be of genetic origin. Although the number of candidate spermatogenesis genes is steadily increasing, their pathogenic role is largely unknown. A recent report focused on gene polymorphisms as a cause for impairment of sperm production and male infertility [2].

The mitochondrial DNA polymerase gamma (POLG) gene is located on chromosome 15q24 and contains a polymorphic CAG repeat [3]. The com- 
mon allele contains $10 \mathrm{CAG}$ repeats and occurs at a uniformly high frequency (88-96\%) in Eurasian populations [4-6]. The not10 CAG repeat alleles (ranging from six to 15) are considered as mutants. Rovio et al. [3] reported a strong association between the absence of the 10 CAG allele and male infertility, specifically with moderate oligozoospermia, and hypothesized that the presence of two mutant alleles would lead to a suboptimal polymerase activity with accumulation of mutations in mtDNA, impaired energy metabolism in the spermatogenic cells and disturbance of sperm production and/or differentiation. Later Jensen et al. [7] suggested that the POLG gene polymorphism should be considered as a possible contributing factor in patients with unexplained subfertility and normal semen parameters. However, studies in Italy [8,9] and France [10] did not confirm any influence of the POLG CAG polymorphism on the efficiency of spermatogenesis and male fertility. Recently, a difference has been reported in the number of CAG repeats of the POLG gene between Chinese and European males, and it was proposed that the 10/not 10 CAG genotype may affect sperm motility n Chinese males [11]. The aim of this study was to assess whether different POLG CAG alleles are associated with impaired spermatogenesis and infertility/subfertility in Macedonian men.

\section{MATERIALS AND METHODS}

Subjects. A total of 225 male patients attending the Andrology Outpatient Unit at the Clinic for Endocrinology and Metabolic Disorders, Faculty of Medicine, Skopje, R. Macedonia, were enrolled in the study. All gave informed consent to participate in the study. Semen analysis was performed in accordance with World Health Organization (WHO) guidelines [12]. All patients were routinely screened for the presence of sex chromosomal aneuploidies by QF polymerase chain reaction (PCR) analysis and for the presence of Y micro deletions by multiplex PCR analysis of several STS sites in the three AZF regions $[13,14]$. The group with known causes of infertility included 29 patients; 10 had Y micro deletions, eight were XXY patients, two were XX, one was XYY and eight had obstructive azoospermia. The other 196 patients were divided into four subgroups according to the severity of the spermatogenic defect as determined by semen analysis: azoospermia, $n=74$; se- vere oligozoospermia $\left(<5 \times 10^{6} / \mathrm{mL}\right), n=56$; mild oligozoospermia $\left(>5 \times 10^{6} / \mathrm{mL}\right), n=27$; and normozoospermia, $n=39$. In addition, 123 men who have fathered at least one child by natural conception and whose paternity was proven by DNA analysis, served as controls.

Methods. Genomic DNA was isolated from leukocytes using the Proteinase K/SDS digestionphenol/ chloroform extraction-ethanol precipitation method [15]. The POLG CAG repeat number was determined by fluorescent PCR amplification of exon 2 using the following primers: direct 5'-ROX-CCA GCT CCG TCC CCG CGT CCG ACC-3' and reverse 5'-GCT GCC CGC CCT CCG AGG ATA GCA C-3'. The size of the PCR product was determined by capillary electrophoresis on an ABI PRISM ${ }^{\mathrm{TM}} 310$ Genetic Analyzer (Applied BioSystems, Foster City, CA, USA) and the size of the PCR products was determined by GeneScan software (Figure 1). The number of CAG repeats predicted by the GenesScan software was compared with the actual CAG repeats determined by direct dideoxy terminator cycle sequencing using a Big Dye Terminator Sequencing Kit v1.0 (Applied BioSystems) in male DNA samples homozygous for 10 and $11 \mathrm{CAG}$ repeats.

Statistical Analysis. Statistical analysis was performed using Chi square and Fisher's exact test. A $p$ value of $<0.05$ was considered statistically significant for each test.

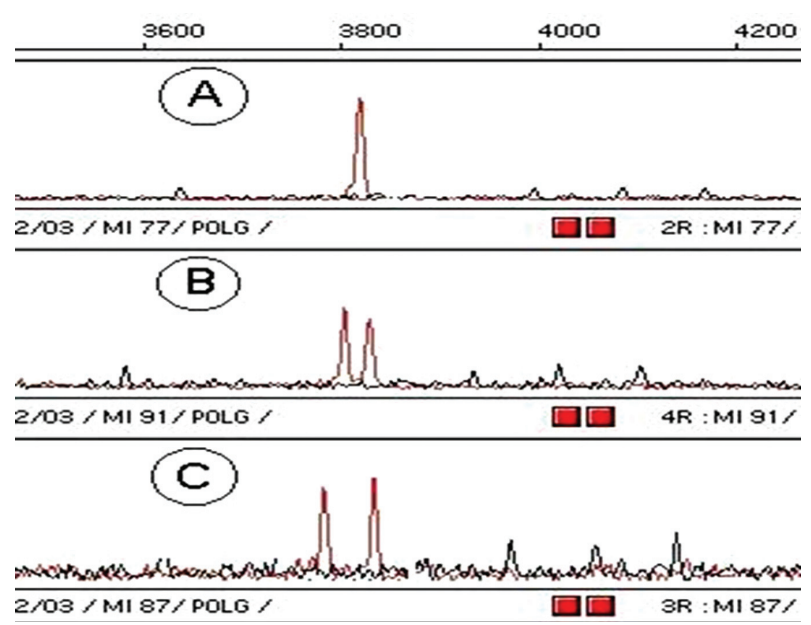

Figure 1. Electrophoreogram obtained on an ABI PRISMTM 310 Genetic Analyzer (Applied BioSystems) from patients with different POLG CAG genotypes: A) 10/10; B) $10 / 11$; C) 9/11. 


\section{RESULTS}

Six different alleles that contained from 7 to 12 CAG repeats were detected in the 696 alleles studied (Table 1). The most frequently observed POLG allele was the common allele of $10 \mathrm{CAG}$ repeats with a frequency of $87.6 \%$ in the infertile/subfertile group and $86.6 \%$ in the control group of fertile males. The frequency of the allele of $10 \mathrm{CAG}$ repeats was similar in all five subgroups of infertile/subfertile patients ranging from $85.1 \%$ in the azoospermia group to $90.2 \%$ in the severe oligozoospermia group. The second most frequent allele contained $11 \mathrm{CAG}$ repeats, ranging from $8.0 \%$ in severe oligozoospermia group to $11.5 \%$ in the azoospermia group. The other four POLG CAG alleles were extremely rare.

The frequency of the different POLG CAG genotypes is given in Table 2 . The most frequent genotype was the $10 / 10,76.9 \%$ in the patient group, $74.8 \%$ in the control group. This genotype was designated as a homozygous wild type [3]. Five heterozygous genotypes $(7 / 10,8 / 10,9 / 10,11 / 10,12 / 10)$ and two homozygous mutant genotypes (9/11 and 11/11) were

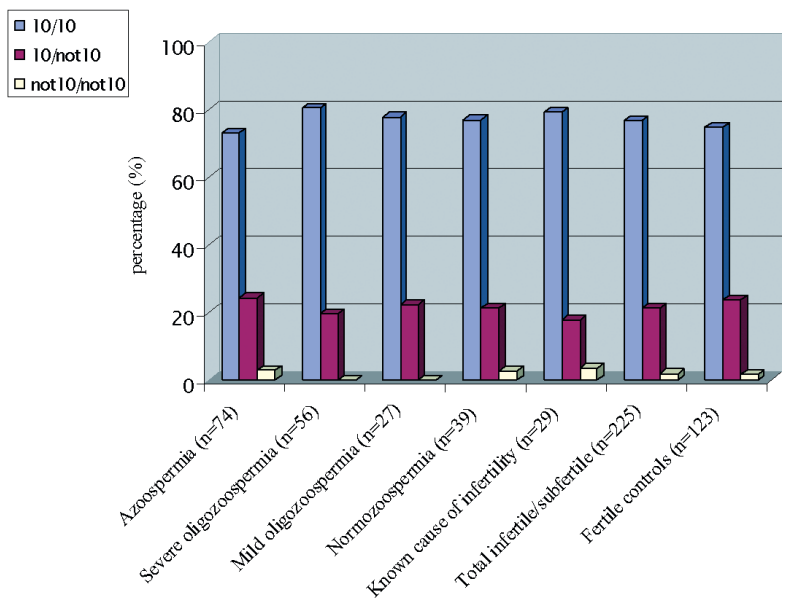

Figure 2. Distribution of POLG CAG genotypes in different groups of infertile/subfertile patients and fertile controls.

also found. The distribution of the 10/10, 10/not10 and not10/not 10 genotypes is shown in Figure 2. Homozygous mutant genotypes were found in the control group (two 11/11), azoospermia group (two: one $9 / 11$ and one 11/11), normozoospermia group (one

Table 1. Allele frequency of the POLG CAG repeats in different groups of infertile/subfertile males and fertile controls

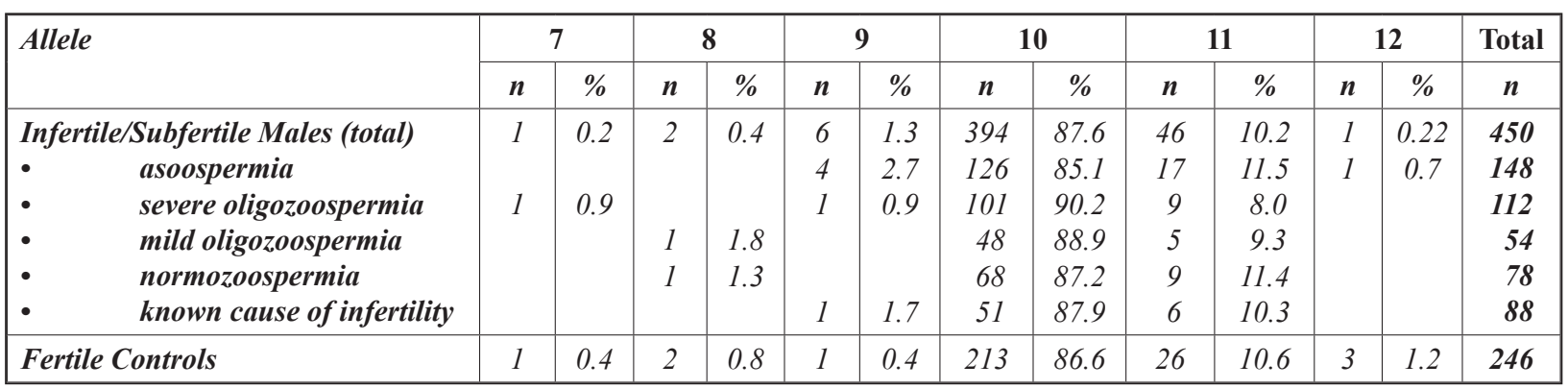

Table 2. Genotype frequency of the POLG CAG repeats in different groups of infertile/subfertile males and fertile controls

\begin{tabular}{|c|c|c|c|c|c|c|c|c|c|c|c|c|c|c|c|c|c|}
\hline \multirow[t]{2}{*}{ Genotype } & \multicolumn{2}{|c|}{$10 / 10$} & \multicolumn{2}{|c|}{$7 / 10$} & \multicolumn{2}{|c|}{$8 / 10$} & \multicolumn{2}{|c|}{$9 / 10$} & \multicolumn{2}{|c|}{$10 / 11$} & \multicolumn{2}{|c|}{$12 / 12$} & \multicolumn{2}{|c|}{ 9/11 } & \multicolumn{2}{|c|}{$11 / 11$} & \multirow{2}{*}{$\begin{array}{c}\text { Total } \\
n\end{array}$} \\
\hline & $n$ & $\%$ & $n$ & $\%$ & $n$ & $\%$ & $n$ & $\%$ & $n$ & $\%$ & $n$ & $\%$ & $n$ & $\%$ & $n$ & $\%$ & \\
\hline $\begin{array}{l}\text { Infertile/Subfertile Males (total) } \\
\cdot \\
\cdot\end{array}$ & $\begin{array}{r}173 \\
54 \\
45 \\
21 \\
30 \\
23\end{array}$ & $\begin{array}{r}76.9 \\
73.0 \\
80.4 \\
77.8 \\
76.9 \\
79.3\end{array}$ & 1 & $\begin{array}{l}0.4 \\
1.8\end{array}$ & $\begin{array}{l}1 \\
1\end{array}$ & $\begin{array}{l}3.7 \\
2.6\end{array}$ & $\begin{array}{l}5 \\
3 \\
1\end{array}$ & $\begin{array}{l}2.3 \\
4.0 \\
1.8\end{array}$ & $\begin{array}{r}39 \\
14 \\
9 \\
5 \\
7 \\
4\end{array}$ & $\begin{array}{l}17.4 \\
18.8 \\
16.1 \\
18.5 \\
17.9 \\
13.7\end{array}$ & $\begin{array}{l}1 \\
1\end{array}$ & $\begin{array}{l}0.4 \\
1.4\end{array}$ & $\begin{array}{l}1 \\
1\end{array}$ & $\begin{array}{l}0.4 \\
1.4\end{array}$ & $\begin{array}{l}3 \\
1\end{array}$ & $\begin{array}{l}1.3 \\
1.4\end{array}$ & $\begin{array}{r}225 \\
74 \\
56 \\
27 \\
39 \\
29\end{array}$ \\
\hline Fertile Controls & 92 & 74.8 & 1 & 0.8 & 2 & 1.6 & 1 & 0.8 & 22 & 17.9 & 3 & 2.4 & & & 2 & 1.6 & 123 \\
\hline
\end{tabular}


11/11) and the known cause group (one 11/11) (Table 2 and Figure 2). No homozygous mutant genotypes were found in the severe and mild oligozoospermia groups. The relatively higher frequency of the homozygous mutant genotypes in these three groups $(2.8,2.6$ and $3.5 \%)$ in comparison with the control group $(1.6 \%)$ was not statistically different.

\section{DISCUSSION}

Whereas two related studies have indicated a relationship between the presence of the not 10/not10 genotype and oligo(astheno)zoospermia [3] and unexplained subfertility [7], we have found the homozygous mutant genotype to have a similar frequency in infertile/subfertile patients and fertile controls. We observed no significant difference in the distribution of the three POLG genotypes (homozygous wild, heterozygous and homozygous mutant) in our five subgroups of patients (azoospermia, severe oligozoospermia, mild oligozoospermia, normozoospermia and known cause of infertility). These results agree with those of three other studies [8-10], and suggest that the POLG CAG polymorphism does not play a significant role in male infertility/subfertility. Similarly in vitro studies have shown that deletion of the CAG repeat has no detectable effect on mitochondrial function [16]. A recent meta-analysis presenting a summary of the polymorphisms that have been associated with male fertility, also revealed no significant association between POLG polymorphism and male fertility [2]. In conclusion, we have found no association between polymorphism of the POLG gene and infertility in Macedonian men.

\section{ACKNOWLEDGMENTS}

This study was supported by grant No. 13-1000/3-05 from the Ministry of Education and Science, Skopje, R. Macedonia (to D. PlaseskaKaranfilska).

\section{REFERENCES}

1. Carlsen E, Giwercman A, Keiding N, Skakkebaek NE. Evidence for decreasing quality of semen during past 50 years. BMJ 1992; 305(6854): 609-613.

2. Tüttelmann F, Rajpert-De Meyts E, Nieschlag
E, Simoni M. Gene polymorphisms and male infertility-a meta-analysis and literature review. Reprod Biomed Online 2007; 15(6): 643-658.

3. Rovio AT, Marchington DR, Donat S, Schuppe HC, Abel J, Fritsche E, Elliott DJ, Laippala P, Ahola AL, McNay D, Harrison RF, Hughes B, Barrett T, Bailey DM, Mehmet D, Jequier AM, Hargreave TB, Kao SH, Cummins JM, Barton DE, Cooke HJ, Wei YH, Wichmann L, Poulton J, Jacobs HT. Mutations at the mitochondrial DNA polymerase (POLG) locus associated with male infertility. Nat Genet 2001; 29(3): 261-262.

4. Ropp PA, Copeland WC. Cloning and characterization of the human mitochondrial DNA polymerase, DNA polymerase gamma. Genomics 1996; 36(3): 449-458.

5. Rovio A, Tiranti V, Bednarz AL, Suomalainen A, Spelbrink JN, Lecrenier N, Melberg A, Zeviani M, Poulton J, Foury F, Jacobs HT. Analysis of the trinucleotide CAG repeat from the human mitochondrial DNA polymerase gene in healthy and diseased individuals. Eur J Hum Genet 1999; 7(2): 140-146.

6. Malyarchuk BA, Papuga M, Grzybowski T, Rogozin IB, Wozniak M, Derenko MV, Rychkov SY, Czarny J, Zakharov IA, Miœcicka-Sliwka D. Low variability of the POLG (CAG)n repeat in north Eurasian populations. Hum Biol 2005; 77(3): 355-365.

7. Jensen M, Leffers H, Petersen JH, Nyboe Andersen A, Jørgensen N, Carlsen E, Jensen TK, Skakkebaek NE, Rajpert-De Meyts E. Frequent polymorphism of the mitochondrial DNA polymerase gamma gene (POLG) in patients with normal spermiograms and unexplained subfertility. Hum Reprod 2004; 19(1): 65-70.

8. Krausz C, Guarducci E, Becherini L, Degl'Innocenti S, Gerace L, Balercia G, Forti G. The clinical significance of the POLG gene polymorphism in male infertility. J Clin Endocrinol Metab 2004; 89(9): 4292-4297.

9. Aknin-Seifer IE, Touraine RL, Lejeune H, Jimenez C, Chouteau J, Siffroi JP, McElreavey K, Bienvenu T, Patrat C, Levy R. Is the CAG repeat of mitochondrial DNA polymerase gamma (POLG) associated with male infertility? A multi-centre French study. Hum Reprod 2005; 20(3): 736-740.

10. Brusco A, Michielotto C, Gatta V, Foresta C, Matullo G, Zeviani M, Ferrari G, Dragone E, Calabrese G, Rossato M, Stuppia L, Migone N. The polymorphic polyglutamine repeat in the mitochondrial 
DNA polymerase gamma gene is not associated with oligozoospermia. J Endocrinol Invest 2006; 29(1): $1-4$.

11. Yao N, Zheng JF, Peng YF, Li ZX, Peng ZQ, Jin $\mathrm{XH}$, Ma X. CAG repeats of DNA polymerase gamma in Chinese males and relationship of idiopathic male infertility to CAG repeats. Zhonghua Nan Ke Xue 2006; 12(8): 681-684.

12. World Health Organization. Laboratory Manual for the Examination of Human Semen and Semen Cervical Mucus Interaction, 4th ed. Cambridge: Cambridge University Press. 1999.

13. Plaseski T, Dimitrovski C, Kocevska B, Efremov DG, Plaseska-Karanfilska D. The prevalence of Y chromosome microdeletions among infertile males from the Republic of Macedonia. Balkan J Med Genet 2003; 6(1\&2): 39-44.
14. Plaseski T, Noveski P, Kocevska B, Dimitrovski C, Efremov GD, Plaseska-Karanfilska D. AZF deletions in infertile men from the Republic of Macedonia. Prilozi 2006; 27(1): 5-16.

15. Efremov GD, Dimovski AJ, Plaseska-Karanfilska D, Simjanovska L, Sukarova E, Koceva S. Isolation of genomic DNA from mammalian cells. In: Efremov GD, Ed. A Laboratory Manual, 3rd ed. Skopje: Macedonian Academy of Sciences and Arts. 1999; 1-3.

16. Spelbrink JN, Toivonen JM, Hakkaart GA, Kurkela JM, Cooper HM, Lehtinen SK, Lecrenier N, Back JW, Speijer D, Foury F, Jacobs HT. In vivo functional analysis of the human mitochondrial DNA polymerase POLG expressed in cultured human cells. J Biol Chem. 2000; 275(32): 24818-24828. 
